\title{
THE RELATIONSHIPBETWEEN CEO COMPENSATION AND COMPANY PERFORMANCES
}

\author{
Segaf \\ Fakultas Ekonomi,Universitas Islam Negeri Maulana Malik Ibrahim Malang \\ Jl. Gajayana 50 Malang Telp. 0341-551354 Faks. 0341-572533 \\ Email: No Telepon: 0819826919
}

\begin{abstract}
Abstrak
Akhir-akhir ini gaji CEO (Chief Executive Officers) telah menyita perhatian investor, masyarakat, bahkan media terkait dengan kinerja perusahaan. Artikel ini mengkaji dan menganalisa keterkaitan antara gaji CEO dengan kinerja perusahaan. Walaupun pertanyaan ini telah dikaji oleh peneliti terdahulu namun kebanyakan dilakukan di negara maju seperti Amerika dan Inggris. Pengumpulan data melalui laporan keuangan tahunan, program Data Stream Thompson dan Laporan Rapat Umum Pemegang Saham. Tiga puluh perusahaan digunakan sebagai sample dari lebih 500 perusahaan terdaftar di KLSE (Kuala Lumpur Stock Exchange). Pengambilan sample menggunakan metode simple random sampling dengan tujuan untuk memberikan kesempatan yang sama pada penelitian ini. Pada penelitian ini pengukuran kinerja perusahaan melalui ROE (Return on Equity), ROA (Return on Asset), EPS (Earning per Share) dan NPM (Net Profit Margin) selama enam tahun (2003-2008) berdasar perhitungan tahunan. Kemudian data dianalisa melalui analisis deskriptif dan analisa regresi Anova. Hasil penelitian ini bahwa gaji tertinggi perusahaan oleh Genting Berhad, selama tahun 2008 merupakan tahun terbaik berinvestasi bagi tipe investor penghindar resiko, selama tahun 2003-2007 terdapat pengaruh yang signifikan antara gaji CEO dan kinerja perusahaan sedangkan pada tahun 2008 tidak terdapat pengaruh yang signifikan antara gaji CEO dan kinerja perusahaan.
\end{abstract}

Kata kunci : Gaji CEO, kinerja perusahaan

\section{INTRODUCTION}

The issue of directors' compensation is tied closely to the issue of corporate governance has become an increasingly important in most countries around the globe included the Malaysia. Over the past few years, Chief Executive Officer (CEO) compensation attracts the investors, media, public attention regarding to their performance in the company. From investors perspective view, the executive pay and incentive that they arranged is closely aligned to the company performance. In order to determine the CEO compensation it depends on the size of company, the age and tenure of the CEO, their performance etc. In this paper, we examined and analyzed whether there are a relationship between CEO compensation and company performance. Although this question has been studies among the past researchers but they were investigates on Chief Executive Officer's has been concentrated on few developed countries such as the U.S and U.K. Therefore it would be a great opportunity to carry out this question and focusing on Malaysian publicly traded companies in Kuala Lumpur Composite Index $(\mathrm{KLCl})$. Furthermore, a better 
understanding of the CEO compensation is due to the performance measure and compensation structure.

This issue has created impacts which are far more complex because of good corporate governance should constrain excessive payments being made to directors and remuneration should be largely determined by the firm's performance. This has resulted in the analysis of rationales, strategies and mechanism that's respond to the changes in the CEO compensation. Unlike in the U.S or U.K, According to Thillainathan (1999), the concentration of shareholdings through cross holding and pyramid are very common ownership patterns in Malaysia. These companies are being run and dominated by large shareholders who could lead to insiders maximizing their private benefits at the expense of the minority shareholders through director's compensation packages (Thillainathan, 1999). The previous studies have focused mainly on the return on equity (ROE) for the related companies and evaluate the actual cash payments to the CEO.

\section{PROBLEM STATEMENT}

In Malaysia few studies have analyzed the relationship between Chief Executive Officers' (CEO) compensation and firm performance. According to Jensen and Meckling (1976), scholars hold that executive compensation is mostly tied to company performance. However, Bebchuk and Fried (2004) argued that pay is not related to company performance since managers have substantial bargaining power over their boards. Thus, CEOs may have the ability to influence the structure, level, and performance of their compensation payment. Furthermore, the previous studies which is conducted by Veliyath and Bishop (1995), Akhigbe, Madura and Tucker (1995), they found a strong relationship between CEO compensation and company performance. This study is important in order to recognize what parameters that can be used in order to evaluate CEO performance. Almost all studies are done in developed countries such as U.K and U.S but there is lack of researchers about the CEO compensation in Malaysian companies. Therefore, in this study we analyzed the factors that related in order to analyze the relationship.

\section{OBJECTIVES}

In conducting this project paper, there are some objectives need to be achieved. The general objective is to investigate a range of variables that seem to affect the relationship between CEO compensation and company performance. The objective of this study includes examining the following: (1) To study if there any correlation between CEO compensation and company performance among Malaysian's listed companies traded on the KLSE. (2) To find out whether compensation structure or any other CEO related variables affected CEO compensation? 


\section{LIMITATION}

This study only stress on several variables that related with the relationship between CEOs compensation and company performance. These variable are adapted from previous studies by Attaway (2000), Akhigbe, Madura, and Tucker (1995), Madura, Martin and Jessel (1996); and Hall and Liebman (1998). These studyers have applied similar model to their studies. However, we made a few modifications of this model and come up with the study model or theoretical frame work presented in Figure 1.

Another limitation on this study is related to sample whereby our sample is gain from the secondary data which is data stream, KLSE site, and from the companies annual report its self. However, this will reduce the risk of bias because of all this annual report already audits by accredited accountants before they publish to the publics.

\section{LITERATURE REVIEW}

To review this study, the literature review has examined the conceptual of the performance, compensation structure and CEO variables in deeply. The definition and the concept of the study are defined from the previous study about each variables involved. This chapter also reviewed the concept of the variable of this study based on the previous study on this topic and the continuation with the present study. Several previous studies are presented in the table below: 
Table 1: Liteature Review

\begin{tabular}{|c|c|c|c|c|c|}
\hline NO & AUTHORS & TITLE & SAMPLE & METHODOLOGY & RESULT \\
\hline 1 & $\begin{array}{l}\text { Henry L. Tosi, } \\
\text { Jr. and Luis R. } \\
\text { Gomez-Mejia }\end{array}$ & $\begin{array}{l}\text { CEO } \\
\text { Compensation } \\
\text { Monitoring and } \\
\text { Firm } \\
\text { Performance }\end{array}$ & $\begin{array}{l}\text { The data for study } 1 \text { were } \\
\text { collected in spring } 1986 \text {. They } \\
\text { sent a questionnaire to a sample } \\
\text { of } 500 \text { CCOs selected randomly } \\
\text { from manufacturing firms that } \\
\text { were members of the American } \\
\text { Compensation Association (Tosi } \\
\& \quad \text { Gomez-Mejia, 1989). } \\
\text { Responses were received from } \\
175 \text { firms, or } 35 \text { percent. The data } \\
\text { for study } 2 \text { were collected in } \\
\text { February } 1988 \text {. We sent a } \\
\text { questionnaire similar to that used } \\
\text { in study }\end{array}$ & \begin{tabular}{|ll} 
1. & Firm Performance \\
& Analysis \\
& a. Level of profitability \\
& b. Stock Performance \\
& C. Principal Axis Method \\
2. & CEO Monitoring Scale \\
3. Ownership Structure \\
4. & Firm Size
\end{tabular} & $\begin{array}{l}\text { The firm performing well reported } \\
\text { higher level of CEO compensation } \\
\text { monitoring }\end{array}$ \\
\hline 2 & $\begin{array}{l}\text { Giorgio } \\
\text { Canarella and } \\
\text { Arman } \\
\text { Gasparyan }\end{array}$ & $\begin{array}{l}\text { New insights } \\
\text { into executive } \\
\text { compensation } \\
\text { and firm } \\
\text { performance }\end{array}$ & $\begin{array}{l}\text { structural change of the pay to } \\
\text { performance relationship. The } \\
\text { empirical analysis extends over } \\
\text { the period 1996-2002 }\end{array}$ & $\begin{array}{l}\text { The authors use two } \\
\text { measures of performance, } \\
\text { total } \\
\text { shareholder return and } \\
\text { return on assets, and } \\
\text { concentrate on total CEO } \\
\text { compensation, which } \\
\text { includes stock option } \\
\text { compensation, as equity- } \\
\text { based compensation } \\
\text { practices have been } \\
\text { prevalent in new economy } \\
\text { firms. }\end{array}$ & $\begin{array}{l}\text { There is evidence however that } \\
\text { the effect of firm size on CEO } \\
\text { compensation is more significant } \\
\text { after the stock market crash of } \\
2000 \text {. The opposite holds true for } \\
\text { the estimates on firm } \\
\text { performance. In addition, } \\
\text { estimates on firm performance are } \\
\text { more sensitive to the estimation } \\
\text { method and the specification of } \\
\text { the error structures. }\end{array}$ \\
\hline 3 & $\begin{array}{l}\text { Jonathan } \\
\text { Leonard }\end{array}$ & $\begin{array}{ll}\text { Executive } & \text { Pay } \\
\text { and } & \text { Firm } \\
\text { Performance }\end{array}$ & $\begin{array}{l}\text { Survey of executive and } \\
\text { managerial compensation at a few } \\
\text { hundreds major US Corporations } \\
\text { between 1981-1985 }\end{array}$ & $\begin{array}{l}\text { 1. variance analysis of } \\
\text { executive pay } \\
\text { 2. Internal labor Market } \\
\text { Model } \\
\text { 3. Hierarchy Pay } \\
\text { 4. Sorting and The return to } \\
\text { education and experience } \\
\text { 5. Fixed Effect Estimates of } \\
\text { change in Pay } \\
\text { 6. Bonus Pay compared to } \\
\text { Base pay } \\
\text { 7. The effect }\end{array}$ & $\begin{array}{l}\text { The relationship of pay to } \\
\text { corporate performance is U- } \\
\text { Shape: Executive pay is higher in } \\
\text { successful than in failing } \\
\text { companies, but among failing } \\
\text { companies it is higher in those } \\
\text { with heavy losses than in those } \\
\text { with small losses. }\end{array}$ \\
\hline
\end{tabular}




\begin{tabular}{|c|c|c|c|c|c|}
\hline & & & & $\begin{array}{l}\text { compensational system } \\
\text { and organizational } \\
\text { structured to profit }\end{array}$ & \\
\hline 4 & $\begin{array}{l}\text { Richard A. } \\
\text { Lambert, David } \\
\text { F. Larcker, } \\
\text { Keith Weigelt } \\
\text { Strategic } \\
\text { Management } \\
\text { Journal, Vol. } \\
\text { 12, No. } 5 \text { (Jul., } \\
\text { 1991), pp. 395- } \\
402\end{array}$ & $\begin{array}{l}\text { How Sensitive } \\
\text { is Executive } \\
\text { Compensation } \\
\text { to } \\
\text { Organizational } \\
\text { Size? }\end{array}$ & $\begin{array}{l}\text { Annual salary and annual bonus } \\
\text { data collected during } 1982,1983, \\
\text { and } 1984 \text {. } \\
\text { The sample includes the top } \\
\text { executive for the total firm, group, } \\
\text { subgroup, division, and plant. The } \\
\text { sample consists of } 303 \text { large } \\
\text { publicly traded U.S. corporations } \\
\text { which span many sectors of the } \\
\text { economy. }\end{array}$ & $\begin{array}{l}\text { Cross-sectional multiple } \\
\text { linear regression: } \\
\text { 1. Executive compensation } \\
\text { and size in levels } \\
\text { 2. Executive compensation } \\
\text { and corporate and } \\
\text { business unit size } \\
\text { 3. Executive compensation } \\
\text { and size in percentage } \\
\text { changes }\end{array}$ & $\begin{array}{l}\text { The level of corporate CEO } \\
\text { compensation exhibits a positive } \\
\text { and statistically significant cross } \\
\text { sectional association with the } \\
\text { level of firm size. } \\
\text { The adjusted R2 for these } \\
\text { regressions is considerably } \\
\text { smaller than that from the } \\
\text { regressions using measures } \\
\text { expressed as levels. This result } \\
\text { suggests that changes in size, } \\
\text { whether measured at the } \\
\text { corporate or business unit level, } \\
\text { do not exhibit a high correlation } \\
\text { with changes in compensation }\end{array}$ \\
\hline 5 & $\begin{array}{lr}\begin{array}{l}\text { Augustine } \\
\text { Duru }\end{array} & \text { I. } \\
\text { Raghavan } & \mathrm{J} . \\
\text { lyengar } & \\
\text { Managerial } & \\
\text { Finance } & \\
\text { Journal, } & \\
\text { Volume } & 25 \\
\text { Number } 9 & 1999\end{array}$ & $\begin{array}{l}\text { Linking CEO } \\
\text { Pay to Firm } \\
\text { Performance: } \\
\text { Empirical } \\
\text { Evidence from } \\
\text { the Electric } \\
\text { Utility Industry }\end{array}$ & $\begin{array}{l}\text { The initial sample consisted of all } \\
\text { utilities in Standard Industrial } \\
\text { Classification (SIC). } \\
\text { Compensation data were obtained } \\
\text { for } 1992-95 \text { from Standard and } \\
\text { Poor's Compustat Execu Comp. } \\
\text { Final sample of firm- years } \\
\text { contains } 225 \text { observations. }\end{array}$ & \begin{tabular}{|lr} 
Canonical & Correlation \\
Analysis (CCA) used to \\
predicts multiple dependent \\
variables (criterion variables) \\
from multiple independent \\
variables \\
variables)
\end{tabular} & $\begin{array}{l}\text { There is evidence that CEO } \\
\text { compensation and firm } \\
\text { performance are associated when } \\
\text { the overall relationship between } \\
\text { individual components of } \\
\text { compensation and firm } \\
\text { performance measures is } \\
\text { considered simultaneously. } \\
\text { There is a positive association } \\
\text { between changes in short- term } \\
\text { incentive compensation (CHBON) } \\
\text { and changes in market returns } \\
\text { (CHMKRT). } \\
\text { The study also demonstrates that } \\
\text { CEOs' changes in stock options } \\
\text { are more closely tied to changes } \\
\text { in electric utility firms' sales } \\
\text { growth. }\end{array}$ \\
\hline
\end{tabular}




\begin{tabular}{|c|c|c|c|c|c|}
\hline 6 & $\begin{array}{l}\text { Lawrence S. } \\
\text { Tai } \\
\text { Managerial } \\
\text { Finance } \\
\text { Vol. 34 No. 8, } \\
2008 \\
\text { pp. 555-561 } \\
\text { C Emerald } \\
\text { Group } \\
\text { Publishing } \\
\text { Limited }\end{array}$ & $\begin{array}{l}\text { Synchronous } \\
\text { and lagged } \\
\text { relationships } \\
\text { between CEO } \\
\text { pay } \\
\text { and } \\
\text { performance of } \\
\text { quality } \\
\text { companies }\end{array}$ & $\begin{array}{l}\text { The data include annual financial } \\
\text { statement and CEO } \\
\text { compensation information from } \\
\text { the MBNQA winning public } \\
\text { companies from } 1988 \text { to } 2003 \text {. }\end{array}$ & $\begin{array}{l}\text { Causal relationship } \\
\text { (synchronous) between CEO } \\
\text { pay and firm performance as } \\
\text { follows: (1) CEO pay affects } \\
\text { firm performance, (2) firm } \\
\text { performance affects CEO } \\
\text { pay or (3) both (1) and (2). } \\
\text { Causal relationship (lagged) } \\
\text { between CEO pay and firm } \\
\text { performance by } \\
\text { incorporating time as follows: } \\
\text { (1) CEO pay in time t, } t \text { 1 } \\
\text { and t_2 affects firm } \\
\text { performance in time t, (2) } \\
\text { firm performance in time } t \text {, } \\
t \text { t and t_2 affects CEO pay } \\
\text { in time t and (3) both (1) and } \\
\text { (2). }\end{array}$ & $\begin{array}{l}\text { The findings of this study indicate } \\
\text { that there is a synchronous and } \\
\text { lagged relationship between pay } \\
\text { and performance. However, the } \\
\text { direction of causality is mainly } \\
\text { from pay to performance, and not } \\
\text { vice versa. }\end{array}$ \\
\hline 7 & $\begin{array}{l}\text { Mahmoud M. } \\
\text { Nourayi and } \\
\text { Steven M. } \\
\text { Mintz } \\
\text { Managerial } \\
\text { Finance } \\
\text { Vol. 34 No. 8, } \\
\text { 2008 } \\
\text { pp. 524-536 } \\
\text { () Emerald } \\
\text { Group } \\
\text { Publishing } \\
\text { Limited }\end{array}$ & $\begin{array}{l}\text { Tenure, firm's } \\
\text { performance, } \\
\text { and } \\
\text { CEO's } \\
\text { compensation }\end{array}$ & $\begin{array}{l}\text { The study is based on the } \\
\text { Standard and Poor's ExecuComp } \\
\text { data for the } \\
\text { year } 2001 \text { and } 2002 \text {. The sample } \\
\text { consisted of } 2,601 \text { CEO-year } \\
\text { observations from } 1,446 \text { firms of } \\
25 \text { industries. }\end{array}$ & $\begin{array}{l}\text { Regression analysis for cash } \\
\text { compensation and total } \\
\text { compensation. }\end{array}$ & $\begin{array}{l}\text { The firm size appears to be a } \\
\text { significant explanatory variable for } \\
\text { CEOs' cash and total } \\
\text { compensation regardless of CEOs } \\
\text { tenure and measure of } \\
\text { performance. Additionally, firms' } \\
\text { performance is a significant } \\
\text { determinant of cash } \\
\text { compensation for CEOs during } \\
\text { the first three years of their work } \\
\text { as CEOs and not significant for } \\
\text { those with } 15 \text { years or more as } \\
\text { the company's } \\
\text { CEO. Both market-based and } \\
\text { accounting-based performance } \\
\text { measures are negatively } \\
\text { correlated with CEOs' total } \\
\text { compensation regardless of } \\
\text { length of experience. }\end{array}$ \\
\hline 8 & $\begin{array}{l}\text { Brian G. M. } \\
\text { Main } \\
\text { Managerial and } \\
\text { Decision } \\
\text { Economics, } \\
\end{array}$ & $\begin{array}{l}\text { Top Executive } \\
\text { Pay and } \\
\text { Performance }\end{array}$ & $\begin{array}{l}\text { Used data on } 241 \text { of Britain's } \\
\text { Largest industrial Companies in } \\
\text { 1985-1986. }\end{array}$ & $\begin{array}{l}\text { Capital Asset Pricing Model } \\
\text { (Company Indicator } \\
\text { Performance). } \\
\text { Descriptive statistic of top } \\
\text { executive pay by Size } \\
\text { (Sales, Assets and Number }\end{array}$ & $\begin{array}{l}\text { Although top executive pay in } \\
\text { Britain appears to be linked in a } \\
\text { significant way to shareholder } \\
\text { interest, the link is empirically } \\
\text { modest. A weaker link to the } \\
\text { remaining part of abnormal return. }\end{array}$ \\
\hline
\end{tabular}




\begin{tabular}{|c|c|c|c|c|c|}
\hline & $\begin{array}{l}\text { Vol. 12, No. } 3 \\
\text { (Jun., 1991), } \\
\text { pp. 219-229 }\end{array}$ & & & $\begin{array}{l}\text { of Employees) } \\
\text { Regression of top executive } \\
\text { pay by size and indicator } \\
\text { performance) }\end{array}$ & \\
\hline 9 & $\begin{array}{l}\text { John } \\
\text { Boschen and } \\
\text { Kimberly J. } \\
\text { Smith } \\
\text { The Journal of } \\
\text { Business, Vol. } \\
68, \text { No. } 4 \text { (Oct., } \\
\text { 1995), pp. 577- } \\
608\end{array}$ & $\begin{array}{l}\text { You Can Pay } \\
\text { Me Now and } \\
\text { You Can Pay } \\
\text { Me Later: The } \\
\text { Dynamic } \\
\text { Response of } \\
\text { Executive } \\
\text { Compensation } \\
\text { to Firm } \\
\text { Performance }\end{array}$ & $\begin{array}{l}\text { The sample for this study includes } \\
16 \text { firms with complete time series } \\
\text { (i.e., 1948-90), for a total of } 688 \\
\text { firm-years. }\end{array}$ & $\begin{array}{l}\text { Bivariate near-VAR (vector } \\
\text { auto- regression) of } \\
\text { compensation and firm } \\
\text { returns, which allows for the } \\
\text { relationship of firm } \\
\text { performance and CEO } \\
\text { compensation. }\end{array}$ & $\begin{array}{l}\text { First of all, the association } \\
\text { between pay and performance is } \\
\text { strong. } \\
\text { Second, the pattern of a weak } \\
\text { contemporaneous response, } \\
\text { followed by larger subsequent } \\
\text { responses, may explain the } \\
\text { popular view that executives } \\
\text { continue to be rewarded, even for } \\
\text { poor performance }\end{array}$ \\
\hline 10 & $\begin{array}{lr}\text { Mahmoud } & \text { M. } \\
\text { Nourayi and } \\
\text { Frank } \\
\text { Daroca } \\
\text { Managerial } \\
\text { Finance } \\
\text { Vol. 34 No. 8, } \\
\text { 2008 } \\
\text { pp. 562-584 } \\
\text { C) Emerald } \\
\text { Group } \\
\text { Publishing } \\
\text { Limited }\end{array}$ & $\begin{array}{l}\text { CEO } \\
\text { compensation, } \\
\text { firm } \\
\text { performance } \\
\text { and } \\
\text { operational } \\
\text { characteristics }\end{array}$ & $\begin{array}{l}\text { The sample consists of } 455 \text { US } \\
\text { firms from } \\
25 \text { industries, and covers the } \\
\text { period } 1996-2002 \text {. }\end{array}$ & $\begin{array}{l}\text { This study uses the } \\
\text { ExecuComp database as the } \\
\text { information } \\
\text { source. Regression analysis } \\
\text { is used to test hypotheses } \\
\text { that focus on firm size in } \\
\text { terms of sales, market } \\
\text { and accounting returns, and } \\
\text { the number of firm } \\
\text { employees. }\end{array}$ & $\begin{array}{l}\text { Firm size and market-based } \\
\text { return are the most significant } \\
\text { explanatory variables in affecting } \\
\text { executive compensation. More } \\
\text { limited support was found for } \\
\text { accounting-based returns, as was } \\
\text { changes in the number of } \\
\text { employees. }\end{array}$ \\
\hline
\end{tabular}




\section{METHODOLOGY}

\section{Introduction}

As state in the before, the purpose in this study is to examine and analyzed the relationship between Chief Executive Officer's (CEO) and company performance. For this chapter, it describes the methodology that will used to conduct the study. In this chapter also provided the measurement scale on return on equity (ROE), return on assets (ROA), earning per share (EPS), net profit margin (NPM). Besides that, it's also including the measurement of CEO compensation like salaries, bonus and others emoluments. The hypothesis, sampling method and data analysis will also be explained in this chapter.

\section{Theoretical Framework}

Previous studies have suggested that the CEO compensation differ according to the company, industry and compensation structure of the company. In addition, a range of economic and related variables that affected adjustment has also been identified in the previous study such as CEO related variable i.e. CEO age, job tenure etc. Although, previous studies have approached the study of the CEO compensation and company performance through the measurement of one or a limited number of variables, but our study are trying to examine and analyzed a range of variables that seem to affect the CEO compensation.

As mentioned earlier ROE is the measurement used in the previous studies performed. Attaway (2000) notes that ROE as a measurement of company measurement can be criticized as it may not indicate the true underlying performance of the CEO, since this figure can be easily manipulated to make the CEO look goods. Therefore, we have used the model that including return on asset (ROA), earning per share (EPS) and net profit margin (NPM). This model has been applied in previous studies by Murthy and Salter (1975), Akhigbe, Madura, and Tucker (1995); Hall and Liebman (1998). Earlier studies performed by Murthy and Salter (1975); Aupperle, Figler and Lutz (1991) and Madura, Martin and Jessel (1996) found no significant relationship between CEO compensation and changes in ROE. However, Veliyath and Bishop (1995) were able to distinguish that companies with high ROE reward their CEOs with higher compensation. Thus, these results encourage us to see whether other additional variables such as ROA, EPS and NPM had some significant role in the cash compensation for CEOs.

Based on the explanation above, the theoretical framework for this study was exemplified on the Figure 1 below: 


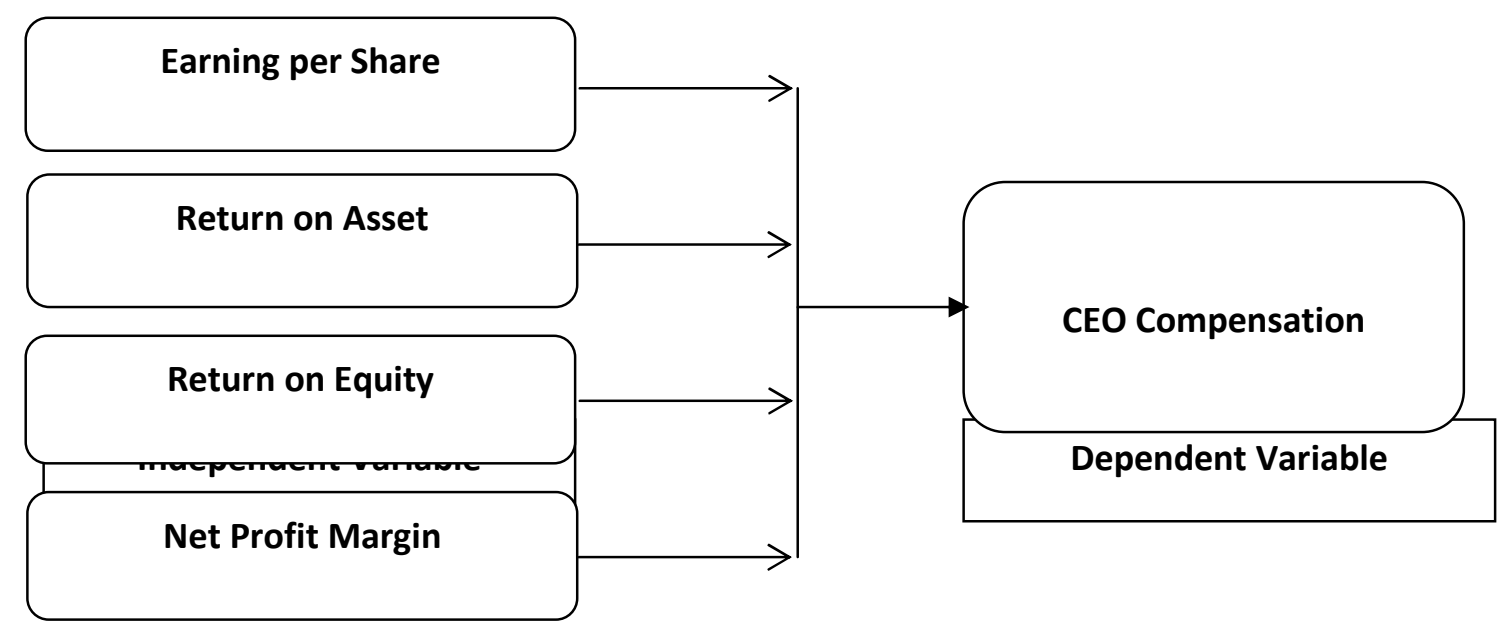

\section{Hypothesis}

Based on the above explanation, there are some hypotheses formulated in this study. They are:

$\mathrm{H}_{0}$ : There is no relationship between companies performances significantly related to CEO Compensation

$\mathrm{H}_{1}$ : There is relationship between companies performances significantly related to CEO Compensation.

\section{Data Sampling}

The sample of this study is consisting of companies listed on the KLSE. There are many listed companies in the KLSE with number exceeds 500 companies. Based on the population there are 30 companies were selected as a sample in order to study about the relationship between CEO compensation and company performance. The data applicable for our studies was found in the annual reports for each selected companies and it were used primarily to collect the CEO specific variables whereas all variable data during six years is calculated on an annual basis. The sampling is using the simple random sampling which the companies have an equal chance to being selected to participate in this study.

\section{Chosen Variables}

\section{Company Performance Variables}

The primary focus of this study is on the relationship between CEO compensation and company performance, although other factors are included in the model as independent variables. In this study, the company performance measures ROE, ROA, EPS and NPM are applied. Even though these are very commonly used performance measures.

\section{CEO's Compensation Variables}

The CEO's may be dependent on each individual's characteristics as well as the specific factors of each company. In this study, we use two compensation measures 
which are the compensation include the cash compensation taken from the base salary and from bonus and other emoluments.

\section{Data analysis}

The data collected will be analyzed using the statistical package for the social science (SPSS) 12.0. The data were summarizing using the appropriate descriptive and inferential statistic and the data collected were analyzed based on the hypotheses that develop in the first chapter. The analysis of each hypothesis as below:

\section{Descriptive statistic}

Descriptive statistics are used to explore the data collected and to summarise and describe those data. It may be particularly useful if the users want to make some general observations about the data collected. In addition, other statistics such as the minimum, maximum and mean will give more information about the distribution of each variable.

\section{Regression ANOVA}

Analysis of the effect of one treatment variable on an interval-sacled or ration-scaled dependent variable; a technique to determine if statistically significance differences in means occur between two or more group variables.

\section{DISCUSSION}

\section{Analysis Statistic Descriptive}

Table 2: CEO Compensation (2003-2008)

\begin{tabular}{|c|r|c|c|}
\hline \multirow{2}{*}{ YEAR } & \multicolumn{3}{|c|}{ CEO Compensation } \\
\cline { 2 - 4 } & Minimum & Maximum & Mean \\
\hline 2003 & 25,000 & $85,040,000$ & $4,923,776$ \\
\hline 2004 & 0 & $57,275,000$ & $4,317,411$ \\
\hline 2005 & 93,700 & $69,223,000$ & $4,951,295$ \\
\hline 2006 & 397,000 & $78,774,000$ & $6,401,646$ \\
\hline 2007 & 506,000 & $101,341,000$ & $6,503,448$ \\
\hline 2008 & 607,000 & $90,759,000$ & $7,263,871$ \\
\hline
\end{tabular}

The data descriptive above shows that the minimum value of CEO Compensation keep increase from 2003-2008, except for 2004. Because that period there is company that do not give compensation for their CEO, which is Takaful Malaysia. Maximum value of CEO Compensation for the last 6 years still holds by Genting Berhad. The highest mean of CEO Compensation in 2008 , even that period is not the highest maximum value $\left(2^{\text {nd }}\right.$ highest with the best minimum value on 2003-2008.) 
Table 3: Earning Per Share (2003-2008)

\begin{tabular}{|c|r|r|r|}
\hline \multirow{2}{*}{ YEAR } & \multicolumn{3}{|c|}{ Earning Per Share } \\
\cline { 2 - 4 } & Minimum & Maximum & Mean \\
\hline 2003 & -44.57 & 108.00 & 19.57 \\
\hline 2004 & 0.37 & 101.34 & 25.98 \\
\hline 2005 & -92.00 & 131.76 & 22.02 \\
\hline 2006 & -177.00 & 176.95 & 22.97 \\
\hline 2007 & -107.30 & 212.87 & 26.31 \\
\hline 2008 & 0.06 & 80.40 & 26.98 \\
\hline
\end{tabular}

The lowest minimum EPS for the last 6 years at amount -177 cent/share by BIMB in 2006. The highest maximum value for EPS given by Genting Berhad in 2007 at amount $212.87 \mathrm{cent} / \mathrm{share}$. Even for 2008 provide the lowest maximum value, but the data above shown the highest mean at 26.98 cent/share. Its mean for Risk Averse Investor this is a good alternative to invest at 2008 in Malaysia.

Table 4: Return on Asset 2003-2008

\begin{tabular}{|c|r|r|r|}
\hline \multirow{2}{*}{ YEAR } & \multicolumn{3}{|c|}{ Return on Asset (ROA) } \\
\cline { 2 - 4 } & Minimum & Maximum & \multicolumn{1}{|c|}{ Mean } \\
\hline 2003 & -0.08 & 0.92 & 0.12 \\
\hline 2004 & -0.18 & 0.11 & 0.04 \\
\hline 2005 & -0.10 & 0.13 & 0.04 \\
\hline 2006 & -0.07 & 0.57 & 0.08 \\
\hline 2007 & -0.08 & 0.93 & 0.09 \\
\hline 2008 & -0.07 & 0.17 & 0.06 \\
\hline
\end{tabular}

The lowest minimum ratio ROA at -0.18 in 2004 by APEX. Its mean at loss-income situation, APEX has a large Total Asset. The highest maximum ratio at 0.93 at 2007, that's mean there is a company that could maximized every single RM of Asset to get RM. 0.93 of return. And the trend is increase from 2004-2007 but decrease again in 2008.

Table 5: Return on Equity 2003-2008
\begin{tabular}{|c|r|r|r|}
\hline \multirow{2}{*}{ YEAR } & \multicolumn{2}{|c|}{ Return on Equity (ROE) } \\
\cline { 2 - 4 } & Minimum & Maximum & \multicolumn{1}{c|}{ Mean } \\
\hline 2003 & -1.02 & 0.90 & 0.11 \\
\hline 2004 & -0.24 & 1.02 & 0.11 \\
\hline 2005 & -0.34 & 0.45 & 0.08 \\
\hline 2006 & -2.62 & 0.80 & 0.05 \\
\hline 2007 & -0.10 & 1.84 & 0.16 \\
\hline 2008 & -0.08 & 0.27 & 0.11 \\
\hline
\end{tabular}

The effect of BIMB loss not only shown at EPS but also shown at ROE ratio with the lowest ratio at -2.62 . That's mean for every single RM of equity, the company suffer in -2.62 loss. The interesting result shown in 2007 with the highest maximum value of ROE come from also BIMB with a ratio 1.84. And its also affect the mean value in 2007 become the highest average at 0.16 . 
Table 6: Net Profit Margin 2003-2008

\begin{tabular}{|c|r|r|r|}
\hline \multirow{2}{*}{ YEAR } & \multicolumn{3}{|c|}{ Net Profit Margin } \\
\cline { 2 - 4 } & Minimum & Maximum & \multicolumn{1}{c|}{ Mean } \\
\hline 2003 & -0.79 & 1.27 & 0.11 \\
\hline 2004 & -0.61 & 1.31 & 0.16 \\
\hline 2005 & -0.42 & 1.06 & 0.10 \\
\hline 2006 & -1.21 & 1.15 & 0.13 \\
\hline 2007 & -0.12 & 1.59 & 0.19 \\
\hline 2008 & -0.23 & 1.78 & 0.17 \\
\hline
\end{tabular}

The same phenomena in Net Profit Margin Ratio, the lowest minimum value at -1.21 in 2006. The positive trend for maximum value, even decrease in 2005 but keep increase until 2008. Its mean that the companies have a good trend to maximized their profit for sales they made. And the highest mean value at 2007 that affected by the best minimum value and the $2^{\text {nd }}$ highest maximum value in same year.

\section{Regression Anova}

An Analysis of Variance (ANOVA) use to examine the significant mean differences among more than two groups on an interval or ratio scaled dependent variable. The result of Anova show whether or not the means of various group are significantly different from one another, as indicated by f-statistic. The $R^{2}$ is the amount of variance explained in the dependent variable by the predictors (Independent Variables). When the $R^{2}$, f statistic and significant level are known then we can interpret the result.

$>$ Regression Anova 2003

Analysis statistic for 2003 shows that there are 55\% of the variance (dependent variable) has been significantly explained by the set of predictor (independent variable) since the sig value $=0.000$ (less than 0.05 ). The statistic formula would be $F_{(4,25)}=$ 7.637; $p<0.05$.

$>$ Regression Anova 2004

Analysis statistic for 2004 shows that there are $35.4 \%$ of the variance (dependent variable) has been significantly explained by the set of predictor (independent variable) since the sig value $=0.023$ (less than 0.05 ). The statistic formula would be $F_{(4,25)}=$ 3.429; $p<0.05$.

$>$ Regression Anova 2005

Analysis statistic for 2005 shows that there are $48.9 \%$ of the variance (dependent variable) has been significantly explained by the set of predictor (independent variable) since the sig value $=0.002$ (less than 0.05 ). The statistic formula would be $F_{(4,25)}=$ $5.987 ; p<0.05$.

$>$ Regression Anova 2006 
Analysis statistic for 2006 shows that there are 55.3\% of the variance (dependent variable) has been significantly explained by the set of predictor (independent variable) since the sig value $=0.000$ (less than 0.05 ). The statistic formula would be $F_{(4,25)}=$ 7.430; $p<0.05$.

$>$ Regression Anova 2007

Analysis statistic for 2007 shows that there are $60.2 \%$ of the variance (dependent variable) has been significantly explained by the set of predictor (independent variable) since the sig value $=0.000$ (less than 0.05 ). The statistic formula would be $F_{(4,25)}=$ 9.467; $p<0.05$

$>$ Regression Anova 2008

Analysis statistic for 2008 shows that the variance (dependent variable) has not been significantly explained by the set of predictor (independent variable) since the sig value $=0.716$ (more than 0.05). The statistic formula would be $F_{(4,25)}=0.528 ; p>0.05$.

\section{CONCLUSION}

Maximum Value for CEO Compensation for the last 6 years given by Genting Berhad. Year 2008 is a good alternative for Risk Averse Investor to invest in Malaysia (mean eps). Analysis statistic by Regression Anova for 2003-2007 shows that the variance (dependent variable) has been significantly explained by the set of predictor (independent variable) since the significant value less than 0.05 . Therefore the null hypothesis rejected. Analysis statistic by Regression Anova for 2008 shows that the variance (dependent variable) has not been significantly explained by the set of predictor (independent variable) since the significant value more than 0.05 . Therefore the null hypothesis accepted.

\section{Reference}

Akhigbe, S., Madura, J., and Tucker, A.L., (1995), "Reexamining the link between executive compensation and corporate performance: A note." American Business Review, 13, 2-83.

Alistair W. Kerr, Howard K. Hall; Stephen A. Kozub; Doing Statistics With SPSS, 2002, SAGE Publications.

Attaway, M.C., (2000), "A study of the relationship between company performance and CEO compensation." American Business Review, January: 77-85.

Augustine I. Duru and Raghavan J. lyengar "Linking CEO Pay to Firm Performance: Empirical Evidence from the Electric Utility Industry" Managerial Finance Journal, Volume 25 Number 91999

Aupperle, K.E., Figler, R.A., and Lutz, R.C., (1991), "Do the in search of excellence firms effectively match CEO compensation to corporate performance?" Journal of Managerial Issues, III(4), 444-457. 
Bebchuk, L. and J. Fried (2004). Pay without Performance. Cambridge, MA and London, England: Harvard University Press.

Brian G. M. Main, "Top Executive Pay and Performance", Managerial and Decision Economics, Vol. 12, No. 3 (Jun., 1991), pp. 219-229

Giorgio Canarella, Arman Gasparyan, (2008) "New insights into executive compensation and firm performance: Evidence from a panel of "new economy" firms, 1996-2002", Managerial Finance, Vol. 34 Iss: 8, pp.537 - 554

Hall, B.J. and Liebman, J.B., (1998), "Are CEOs really paid like bureaucrats?'Quarterly Journal of Economics, August: 653+

Henry L. Tosi, Jr. and Luis R. Gomez-Mejia, "CEO Compensation Monitoring and Firm Performance", Organization Science, Vol. 15, No. 6 (Nov. - Dec., 2004), pp. 657-670

Holmstrom, B.: "Moral Hazard and Observability," Bell Journal of Economics, 10(1979), 7491.

Ivan E. Brick, Oded Palmon and John K. Wald, "CEO Compensation, Director Compensation, and Firm Performance: Evidence of Cronyism?" JCF Special Issue on Corporate Governance, May 2005

Jensen, M. C. \& Meckling, W. H. 1976. Theory of the firm: Managerial behavior, agency costs and ownership structure. Journal of Financial Economics, 3, 305-360

Jeremy J. Foster, Data Analysis Using SPSS for Windows: A Beginners Guide. 1998, SAGE Publications.

John F. Boschen, Augustine Duru, Lawrence A. Gordon, Kimberly J. Smith, "Accounting and Stock Price Performance in dynamic CEO Compensation Arrangement", The Accounting Review, Vol. 78, No. 1 (Jan., 2003), pp. 143-168

John F. Boschen and Kimberly J. Smith, "You Can Pay Me Now and You Can Pay Me Later: The Dynamic Response of Executive Compensation to Firm Performance" The Journal of Business, Vol. 68, No. 4 (Oct., 1995), pp. 577-608

Jonathan S. Leonard, "Executive Pay and Firm Performance", Industrial and Labour Relations Review, Vol.43, No.3, Special Issue (Feb 1990).

Lawrence S. Tai, "Synchronous and lagged relationships between CEO pay and performance of quality companies" Managerial Finance Vol. 34 No. 8, 2008 pp. 555561 (C) Emerald Group Publishing Limited

Madura, J., Martin, A.D., and Jessel, K.A., (1996), "Determinants of CEO compensation in small publicly-traded businesses."American Business Review, 14, 80-88.

Mahmoud M. Nourayi and Frank P. Daroca "CEO compensation, firm performance and operational characteristics” Managerial Finance Vol. 34 No. 8, 2008 pp. 562-584(C) Emerald Group Publishing Limited

Mahmoud M. Nourayi and Steven M. Mintz "Tenure, firm's performance, and CEO's compensation" Managerial Finance Vol. 34 No. 8, 2008 pp. 524-536@C Emerald Group Publishing Limited

Murthy, K.R.S., and Salter, M.S., (1975), "Should CEO pay be linked to results?" Harvard Business Review, 53(3), 66-73. 
R Thillainathan, A Review of Corporate Governance in Malaysia, (March 1999) Banker's Journal, Kuala Lumpur 23, 44

Richard A. Lambert, David F. Larcker, Keith Weigelt, "How Sensitive is Executive Compensation to Organizational Size?", Strategic Management Journal, Vol. 12, No. 5 (Jul., 1991), pp. 395-402

Veliyath, R., and Bishop, J.W., (1995), "Relationship between CEO compensation and firm performance: Empirical evidence of labor market norms." The international Journal of Organizational Analysis, 3(3), 268-283. 